\title{
Increase in ovulation rate after treatment of ewes with bovine follicular fluid in the luteal phase of the oestrous cycle*
}

\author{
Jacqueline M. Wallace and A. S. McNeilly \\ MRC Reproductive Biology Unit, University of Edinburgh, Centre for Reproductive Biology, \\ 37 Chalmers Street, Edinburgh EH3 9EW, U.K.
}

\begin{abstract}
Summary. Administration of charcoal-treated bovine follicular fluid to Damline ewes twice daily (i.v.) from Days 1 to 11 of the luteal phase (Day $0=$ oestrus) resulted in a delay in the onset of oestrous behaviour and a significant increase in ovulation rate following cloprostenol-induced luteolysis on Day 12. During follicular fluid treatment plasma levels of FSH in samples withdrawn just before injection of follicular fluid at $09: 00 \mathrm{~h}$ (i.e. $16 \mathrm{~h}$ after previous injection of follicular fluid) were initially suppressed, but by Day 8 of treatment had returned to those of controls. However, the injection of follicular fluid at 09:00 h on Day 8 still caused a significant suppression of FSH as measured during a 6-h sampling period. Basal LH levels were higher throughout treatment due to a significant increase in amplitude and frequency of pulsatile secretion. After cloprostenol-induced luteal regression at the end of treatment on Day 12, plasma levels of FSH increased 4-fold over those of controls and remained higher until the preovulatory LH surge. While LH concentrations were initially higher relative to those of controls, there was no significant difference in the amount of LH released immediately before or during the preovulatory surge. These results suggest that the increase in ovulation rate observed during treatment with bovine follicular fluid is associated with the change in the pattern of gonadotrophin secretion in the luteal and follicular phases of the cycle.
\end{abstract}

\section{Introduction}

Follicular fluid from a variety of species including sheep (Cummins, O'Shea, Bindon, Lee \& Findlay, 1983), cow (Chappel \& Selker, 1979; de Jong \& Sharpe, 1976; Hermans, Debets, van Leeuwen \& de Jong, 1981; Welschen, Hermans \& de Jong, 1980), pig (Marder, Channing \& Schwartz, 1977; DePaolo, Hirshfield, Anderson, Barraclough \& Channing, 1979; Thomas \& Nikitovitch-Winer, 1984), horse (Miller, Wesson \& Ginther, 1981) and man (di Zerega, Marrs, Roche, Campeau \& Kling, 1983) has been shown to suppress FSH secretion when administered to both sexes of a variety of experimental animals (sheep, monkey, rodent and horse). Bovine follicular fluid has also been demonstrated to delay oestrus in ewes and cows (Miller, Critser, Rowe \& Ginther, 1979; McNeilly, 1984) when given during the preovulatory period. Charcoal treatment of follicular fluid to remove steroids and the use of ovariectomized animals (Welschen, Hermans, Dullaart \& de Jong, 1977; Campbell \& Schwartz, 1979) with or without steroid replacement (Bronson \& Channing, 1978; Miller et al., 1981) has shown that follicular fluid contains a nonsteroidal ovarian substance (inhibin), produced by the granulosa cells (Henderson \& Franchimont, 1983), which operates at the pituitary level to suppress FSH secretion. Inhibin may therefore 
operate alone, additively or synergistically with ovarian steroids to control FSH secretion (Goodman, Pickover \& Karsch, 1981).

In ewes, FSH secretion is sufficient to ensure the development of large antral follicles (4-6 mm diameter) throughout the luteal phase of the cycle and is considered to have a permissive role (see Baird, 1983). The use of exogenous gonadotrophin with FSH-like activity to stimulate additional ovulations (Betteridge, 1981) has led to the suggestion that short-term regulation of FSH may be important in the final control of ovulation. While numerous studies (Findlay \& Cumming, 1976; Bindon, Blanc, Pelletier, Terqui \& Thimonier, 1976; Cahill et al., 1981) have failed to observe differences in the levels of FSH both within and between breeds of sheep with widely different ovulation rates, Lahlou-Kassi, Schams \& Glatzel (1984) have shown that FSH concentrations are higher in ewes of the prolific D'Man breed. It has also been suggested that the secondary FSH surge occurring about $24 \mathrm{~h}$ after ovulation may be involved in the recruitment of small antral follicles for ovulation 17 days later (Cahill et al., 1981). The use of bovine follicular fluid in hamsters (Chappel \& Selker, 1979) and antiserum to FSH in rats (Sheela Rani \& Moudgal, 1977) to suppress the second FSH peak resulted in fewer follicles ovulating at the next oestrus.

The present study was carried out to investigate the role of FSH in follicular development throughout the luteal phase of the ovine oestrous cycle by suppressing plasma levels with bovine follicular fluid from the time of the expected second FSH surge until prostaglandin-induced luteolysis on Day 11 of the luteal phase.

\section{Materials and Methods}

Experimental animals. Sixteen Damline ewes (47\% Finnish Landrace, 24\% East Friesland, 17\% Border Leicester, 12\% Dorset Horn) were studied during the breeding season in Feburary 1983. The ewes were 2 or 3 years old and weighed $46.4 \pm 1.4 \mathrm{~kg}$. They had been exhibiting regular ovarian and oestrous cycles before the start of the experiment as determined by laparoscopy and detection of oestrus records. Throughout the experiment the ewes were housed under natural lighting conditions at Dryden Field Station, Roslin, Midlothian, and had access to food and water ad libitum.

Follicular fluid collection. The bovine follicular fluid used in this study was obtained by aspirating follicles ( $>2 \mathrm{~mm}$ in diameter) from cow ovaries obtained from the local slaughter house. The follicular fluid was aspirated within $4 \mathrm{~h}$ of obtaining the ovaries and stored at $-20^{\circ} \mathrm{C}$ until charcoal extraction to remove steroids.

Charcoal extraction. A known volume of follicular fluid sufficient for all injections was mixed in a sterile beaker with washed charcoal added at a concentration of $5 \mathrm{mg} / \mathrm{ml}$ follicular fluid. This was stirred at room temperature for $1 \mathrm{~h}$ followed by centrifugation at $4^{\circ} \mathrm{C}$ for $30 \mathrm{~min}$ at $1500 \mathrm{~g}$. The fluid was then decanted and stored at $-20^{\circ} \mathrm{C}$ in $20 \mathrm{ml}$ volumes. After charcoal treatment $99 \%$ of the original steroids had been removed.

Experimental design. Oestrus was synchronized by an i.m. injection of $100 \mu \mathrm{g}$ cloprostenol (Estrumate: ICI, Cheshire, U.K.). Day 0 was the day on which oestrous behaviour was first detected using a vasectomized raddled ram. The 8 ewes in the treatment group received $10 \mathrm{ml}$ bovine follicular fluid at $09: 00$ and 17:00 h on Day 1 (oestrus $+24 \mathrm{~h}$ ) to Day 11 of the cycle inclusive. The 8 control ewes remained untreated. Luteal regression was induced at $08: 00 \mathrm{~h}$ on Day 12 of the treatment cycle by using cloprostenol. The subsequent onset of oestrus was assessed by using a vasectomized ram at 12-h intervals $(08: 00$ and $20: 00 \mathrm{~h})$ between 36 and $120 \mathrm{~h}$ after cloprostenol injection. Ovulation rate was determined by laparoscopic examination of the ovaries for corpora lutea between Days 5 and 10.

Blood sampling schedule. Single daily blood samples were taken using $10 \mathrm{ml}$ heparinized Vacutainers (Becton Dickinson UK Ltd, Oxford, U.K.). For more frequent sampling, ewes were 
cannulated on the day before sampling commenced to minimize any possible effects of stress. The cannulae (Branula; 18-gauge, size 2; Armour Pharmaceutical Co Ltd, Eastbourne, U.K.) were placed in the jugular vein, stitched securely to the neck and filled with sterile saline $(9 \mathrm{~g} \mathrm{NaCl} / \mathrm{l})$ containing heparin (20 i.u./ml; Weddel Pharm. Ltd, London, U.K.).

Daily blood samples were taken before the $09: 00 \mathrm{~h}$ injection of follicular fluid throughout the luteal phase of the treatment cycle. On Day 8 of the cycle samples were collected every $15 \mathrm{~min}$ between 10:00 and 16:00 h. After luteal regression samples were taken at 4-h intervals until $122 \mathrm{~h}$ after cloprostenol injection or until $36 \mathrm{~h}$ after oestrus was first detected, whichever was the shortest period. In addition, frequent 15-min samples were withdrawn between 24 and $30 \mathrm{~h}$ after cloprostenol injection. During the subsequent cycle blood samples were taken every 2 nd or 3 rd day until oestrus was detected. Blood samples were centrifuged at $1000 \mathrm{~g}$ for $30 \mathrm{~min}$ and the resulting plasma was stored at $-20^{\circ} \mathrm{C}$. All samples were assayed for $\mathrm{LH}, \mathrm{FSH}$ and prolactin and the daily samples of the treatment and subsequent cycles were assayed for progesterone.

Hormone assays. LH, FSH and prolactin were measured in duplicate by specific doubleantibody radioimmunoassays as described previously (McNeilly \& Andrews, 1974; Martensz, Baird, Scaramuzzi \& Van Look, 1976; McNeilly, McNeilly, Walton \& Cunningham, 1976). The sensitivities of the assays were $0.2 \mathrm{ng} \mathrm{LH}(\mathrm{NIH}-\mathrm{LH}-\mathrm{S} 18) / \mathrm{ml}, 4 \mathrm{ng}$ FSH (NIH-FSH-S14)/ml and 0.4 ng prolactin (NIH-p-S13)/ml. The intra- and inter-assay variations as coefficients of variation (\%) were $4.3 \%$ and $11.6 \%, 3.9 \%$ and $10.6 \%, 5 \cdot 3 \%$ and $11.4 \%$ for LH, FSH and prolactin, respectively. Progesterone concentrations in plasma were measured by radioimmunoassay as described by Djahanbahkch, Swanston, Corrie \& McNeilly (1981); the intra- and inter-assay coefficients of variation were $8.2 \%$ and $15 \%$ respectively and the sensitivity was $0.1 \mathrm{ng} / \mathrm{ml}$. Recovery of progesterone added to $250 \mu$ l sheep plasma was $67 \pm 4 \%$ (s.e.m.; $n=100$ ).

Definitions. An LH rise was considered to be a pulse if the value of two consecutive samples was greater than the mean of the two previous samples (basal value) and the value of at least one of the peak samples exceeded the mean basal value by more than 3 times the intra-assay coefficient of variation of the assay (Backström, McNeilly, Leask \& Baird, 1982).

Onset of oestrus was considered to be the time when a ewe first stood to allow a vasectomized ram to mount/mate her minus $6 \mathrm{~h}$ because of the 12-h intervals between heat detection. Similarly, $2 \mathrm{~h}$ was subtracted from the onset times of the preovulatory LH surge (4-h sampling) which was considered to have occurred when LH levels exceeded $15 \mathrm{ng} / \mathrm{ml}$.

Statistics. Student's $t$ test was used to examine the effects of treatment on onset of oestrus, ovulation rate and duration of the subsequent oestrous cycle. It was also used to analyse the characteristics of the pulsatile secretion of $\mathrm{LH}$ and the preovulatory $\mathrm{LH}$ surge. The differences in hormone concentrations between the two groups were analysed by two-way analysis of variance after $\log$ transformation of the data to remove skewness. Daily FSH concentrations were analysed using lineal contrast analysis to determine when significant changes occurred during the cycle. An $F$ test of significance of regression analysis was applied to changes in FSH during the period of rapid blood sampling in the luteal phase to determine whether the slopes were significantly different from time zero.

\section{Results}

\section{Oestrus and ovulation rate}

Twice daily injections of bovine follicular fluid throughout the luteal phase of the oestrous cycle resulted in a significant delay $(P<0.001)$ in onset of oestrus compared to that of control animals $89.0 \pm 8.5$ (s.e.m.), $\mathrm{N}=8$, compared with $41 \cdot 1 \pm 2.3 \mathrm{~h}, \mathrm{~N}=7$, in controls. Follicular fluid treatment also resulted in a significantly $(P<0.02)$ higher ovulation rate compared to that of controls as assessed by the number of corpora lutea observed at laparoscopy $(3.4 \pm 0 \cdot 3, \mathrm{~N}=8$, 
compared with $2 \cdot 3 \pm 0 \cdot 3 \mathrm{~h}, \mathrm{~N}=8$, in controls). No correlation existed between the delay in onset of oestrus and the subsequent ovulation rate. The number of large follicles ( $>5 \mathrm{~mm}$ diam.) was not significantly different between treatments $(2.3 \pm 0.3$ and $1.9 \pm 0.5$ in controls) and there was no effect of treatment on the subsequent cycle length $(17 \cdot 4 \pm 0 \cdot 7$ days and $18.2 \pm 1 \cdot 3$ days in controls).

\section{Hormone concentrations during treatment}

FSH. Over the first 7 days of treatment plasma concentrations of FSH were significantly lower $(P<0.001)$ in follicular fluid-treated ewes than in controls (Text-fig. 1a). From Day 8 of the cycle onwards no significant differences in FSH concentrations as determined by daily sampling were evident. In spite of this, injection of bovine follicular fluid, at least on Day 8, caused a suppression of FSH levels starting about $2 \mathrm{~h}$ after injection (Text-fig. 2). Linear regression analysis of all individual slopes showed that $7 / 8$ treated ewes had a significantly negative regression with time from injection, contrasting with a significantly positive regression with time in $3 / 8$ control ewes and no change in the remaining 5 control ewes.
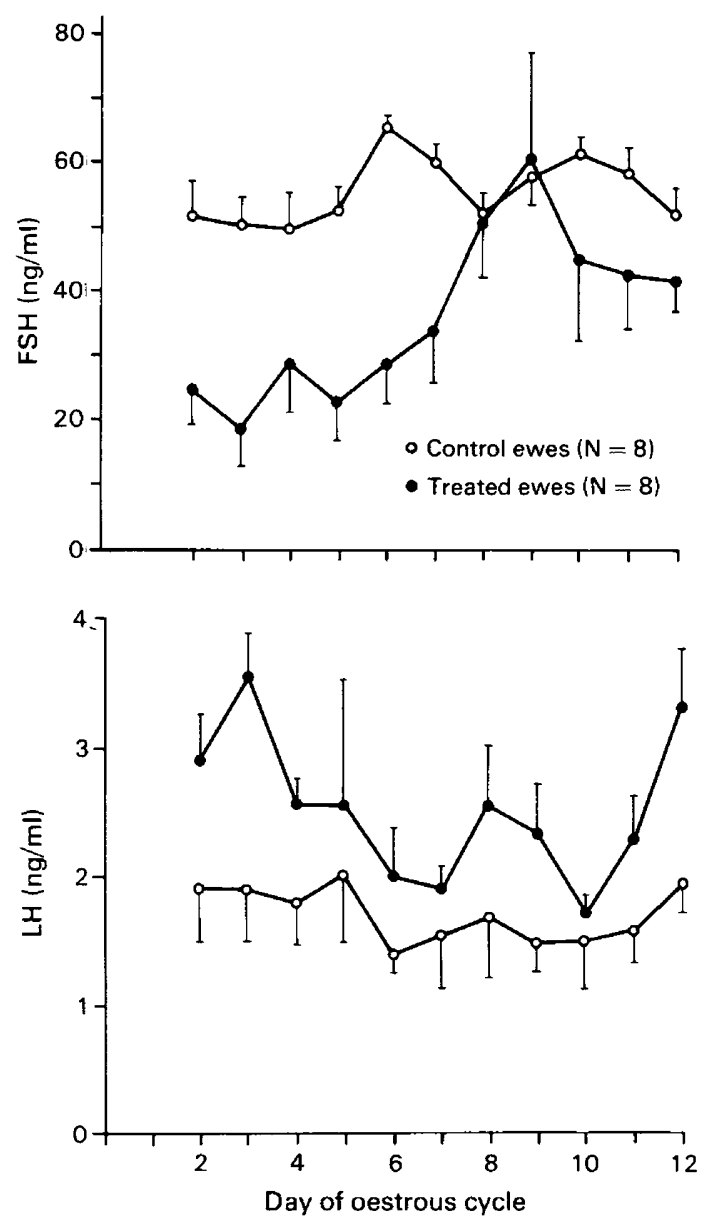

Text-fig. 1. Daily changes (mean \pm s.e.m.) in the concentrations of (a) FSH and (b) LH during the luteal phase of control ewes and animals treated with bovine follicular fluid. Blood samples were collected daily just before the morning injection. 


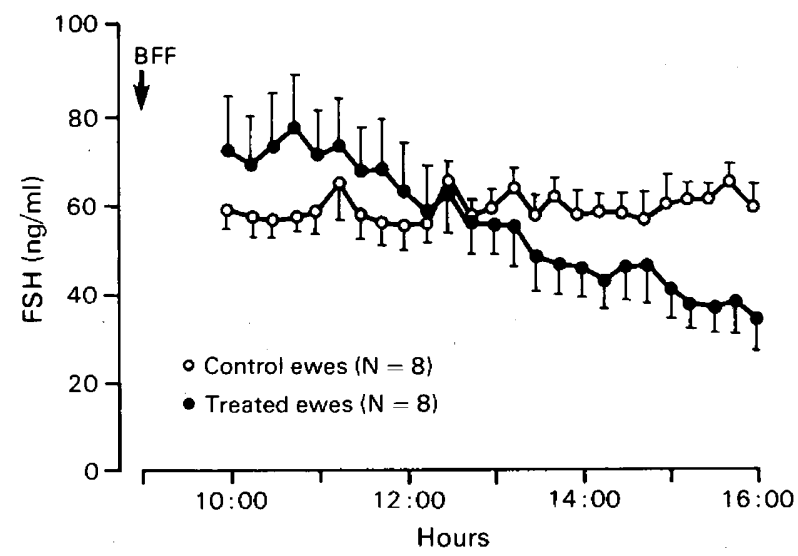

Text-fig. 2. Changes (mean \pm s.e.m.) in the concentrations of FSH in blood samples collected at 15 -min intervals from control ewes and after the i.v. injection of $10 \mathrm{ml}$ bovine follicular fluid (BFF) on Day 8 of the luteal phase.

$L H$. Daily LH concentrations were significantly higher in treated ewes $(P<0.05)$ than in controls throughout the luteal phase (Text-fig. lb). Detailed analysis of the short-term changes in LH on Day 8 of the cycle further indicated that basal LH concentrations, pulse frequency and amplitude were all significantly greater in the treated group $(P<0.02)$ than in the control ewes (Table 1; Text-fig. 3).

Table 1. Effect of treatment of ewes with bovine follicular fluid on pulsatile secretion of LH on Day 8 during the luteal phase and on time to onset of oestrus from cloprostenol-induced luteal regression, characteristics of the preovulatory

LH surge and ovulation rate

\begin{tabular}{|c|c|c|c|}
\hline & $\begin{array}{l}\text { Control ewes } \\
\qquad(\mathrm{N}=8)\end{array}$ & $\begin{array}{l}\text { Treated ewes } \\
\quad(N=8)\end{array}$ & Significance \\
\hline \multicolumn{4}{|l|}{ Day 8: luteal phase } \\
\hline Basal LH (ng/ml) & $1 \cdot 2 \pm 0 \cdot 1$ & $2 \cdot 0 \pm 0 \cdot 2$ & $P<0.01$ \\
\hline LH pulses $/ 6 \mathrm{~h}$ & $1.8 \pm 0.2$ & $2.9 \pm 0.4$ & $P<0.02$ \\
\hline LH pulse amplitude $/ 6 \mathrm{~h}(\mathrm{ng} / \mathrm{ml})$ & $1.6 \pm 0.4$ & $2.9 \pm 0.5$ & $P<0.02$ \\
\hline \multicolumn{4}{|l|}{ Onset of oestrus } \\
\hline Time from cloprostenol (h) & $41 \cdot 1 \pm 2 \cdot 3$ & $89 \cdot 0 \pm 8 \cdot 5$ & $P<0.001$ \\
\hline \multicolumn{4}{|l|}{ LH surge } \\
\hline Onset-time from cloprostenol (h) & $55 \cdot 4 \pm 3 \cdot 7$ & $99 \cdot 0 \pm 7 \cdot 0$ & $P<0.001$ \\
\hline Oestrus to surge (h) & $14 \cdot 3 \pm 2 \cdot 4$ & $8 \cdot 5 \pm 1 \cdot 1$ & N.S. \\
\hline Maximum peak height (ng/ml) & $90 \cdot 5 \pm 9 \cdot 1$ & $79 \cdot 5 \pm 19 \cdot 2$ & N.S. \\
\hline Ovulation rate (range) & $\begin{array}{c}2 \cdot 3 \pm 0 \cdot 3 \\
(1-3)\end{array}$ & $\begin{array}{c}3 \cdot 4 \pm 0 \cdot 3 \\
(2-5)\end{array}$ & $P<0.02$ \\
\hline $\begin{array}{l}\text { No. of large follicles } \\
\text { (>5 mm diam.) }\end{array}$ & $1.9 \pm 0.5$ & $2 \cdot 3 \pm 0 \cdot 6$ & N.S. \\
\hline
\end{tabular}

Values are mean \pm s.e.m.

Prolactin. Plasma levels of prolactin in control and treated ewes throughout the luteal phase were not significantly different (data not shown).

Progesterone. There were no significant differences in plasma progesterone concentrations between groups. Initially, plasma progesterone values were all $<0 \cdot 1 \mathrm{ng} / \mathrm{ml}$, characteristic of 


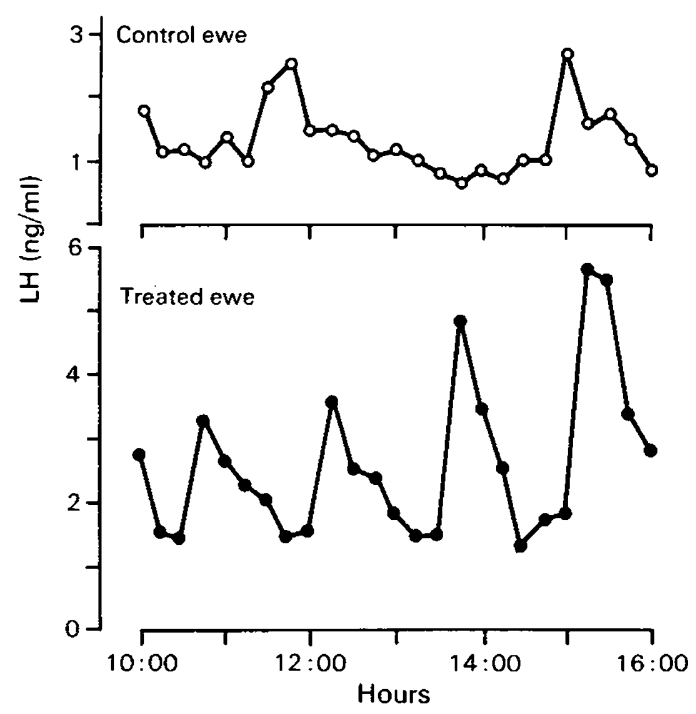

Text-fig. 3. Short-term changes in the concentration of $\mathrm{LH}$ in a control ewe and a ewe injected with $10 \mathrm{ml}$ bovine follicular fluid on Day 8 of the luteal phase.

oestrus. Concentrations began to rise on Days 3-4 of the cycle and reached peak values of $5 \cdot 3 \pm 1 \cdot 6$ and $5.9 \pm 1.7 \mathrm{ng} / \mathrm{ml}$ for the control and treated ewes respectively on Day 12 .

\section{Hormone concentrations after luteal regression}

$F S H$. The changes in plasma levels of FSH after cloprostenol-induced luteal regression are illustrated in Text-fig. 4(a). Mean values increased after luteolysis, reaching a peak of $164 \pm 21 \cdot 8$ $\mathrm{ng} / \mathrm{ml}$ (range 120-224 ng/ml) $14 \mathrm{~h}$ after cloprostenol injection. This represents a 4-fold increase over control group levels of $35.3 \pm 5 \cdot 1 \mathrm{ng} / \mathrm{ml}(24-68 \mathrm{ng} / \mathrm{ml})$ which did not alter significantly after luteolysis. FSH levels in treated ewes were significantly greater $(P<0.005)$ than in controls during the period +2 to $+30 \mathrm{~h}$ after cloprostenol injection. During the 24 -h period before the preovulatory LH surge, FSH concentrations were still higher in the treated group compared with controls but this was not significant. Within this $24-\mathrm{h}$ period, FSH concentrations declined slightly in the treated ewes before the FSH surge which occurred coincident with the preovulatory LH surge in both groups. There was no significant difference in the magnitude of this surge between the two groups. After the preovulatory surge, FSH levels declined and then began to rise again 12-24 $\mathrm{h}$ later to a similar extent in control and treated animals.

$L H$. The changes in plasma LH concentrations after luteolysis are shown in Text-fig. 4(b). The follicular fluid-treated ewes had significantly higher $(P<0.05)$ plasma LH levels in the period 2-30 $\mathrm{h}$ after cloprostenol injection. These differences were diminished towards the end of this period as highlighted by detailed analysis of 15-min samples taken $24-30 \mathrm{~h}$ after cloprostenol. At this time no differences in basal LH concentrations or pulse frequency were found although pulse amplitude was significantly greater $(P<0.05)$ in the treated ewes. There was no significant difference in basal LH concentrations measured in 4-h samples collected in the $24 \mathrm{~h}$ before or after the preovulatory surge or in the magnitude or duration of the preovulatory LH surge between control and treatment groups (Table 1).

The onset of the preovulatory LH surge was significantly later relative to cloprostenol injection in the treatment than control group (Table 1). However, the interval from oestrus to the LH surge did not differ. 

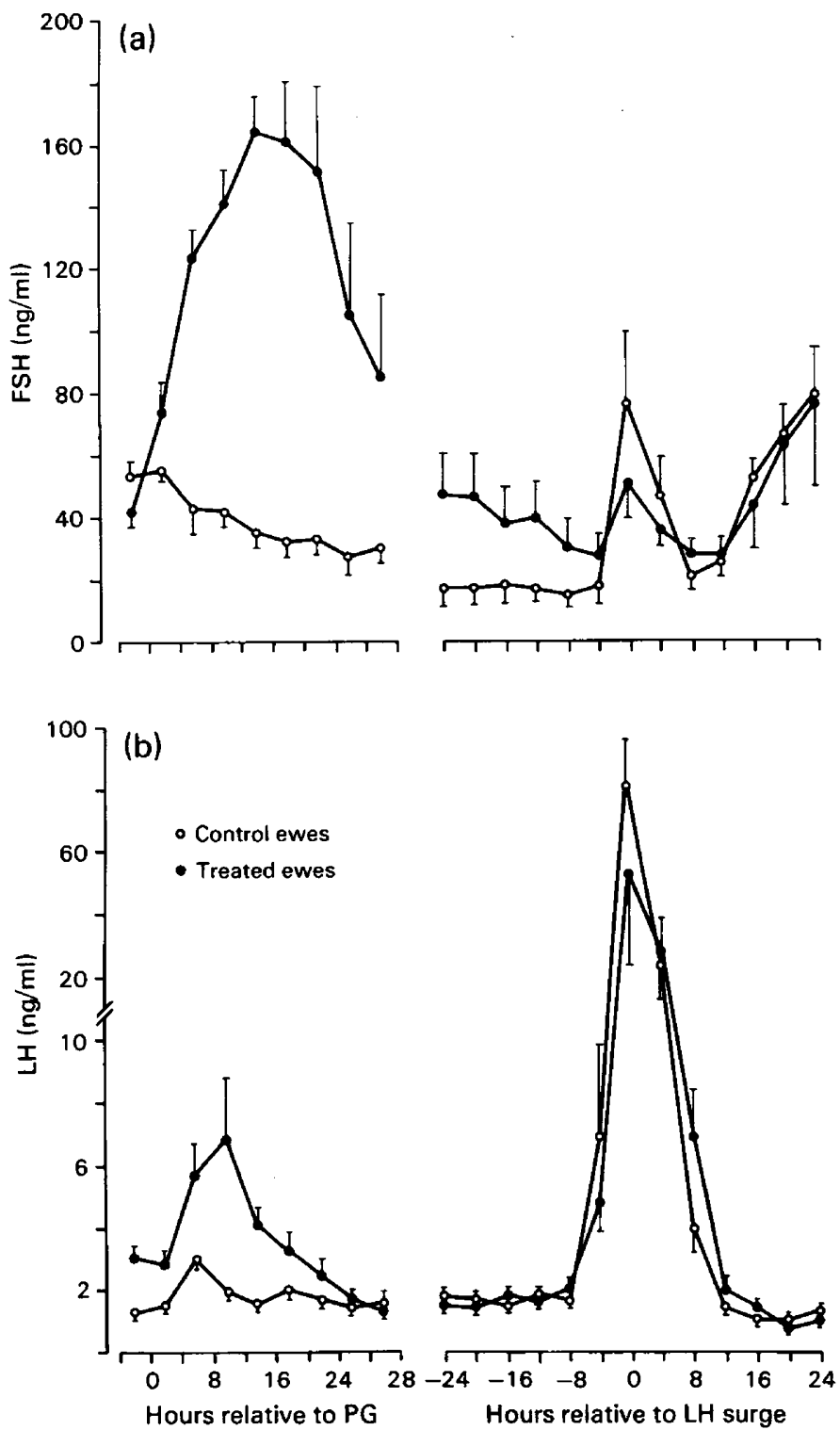

Text-fig. 4. Changes (mean \pm s.e.m.) in the concentrations of (a) FSH and (b) LH after the injection of cloprostenol $(100 \mu \mathrm{g}$ i.m.) on Day 11 of the cycle in control ewes and ewes injected twice daily with bovine follicular fluid throughout the luteal phase. The results have been grouped around the time of the cloprostenol injection (PG) or the LH peak. Blood samples were collected at 4-h intervals.

\section{Subsequent oestrous cycle}

There was no significant effect of treatment on plasma concentrations of FSH, LH or prolactin during the subsequent oestrous cycle. Plasma progesterone levels were characteristic of a normal cycle in ewes of both groups, no differences being found in basal or mid-luteal values in spite of the observed differences in ovulation rate between groups. 


\section{Discussion}

Injections of bovine follicular fluid to ewes in the luteal phase resulted in a significant decrease in plasma FSH concentrations. During the second half of the treatment period FSH levels were no longer suppressed as measured by a daily blood sample collected immediately before the injection of follicular fluid at $09: 00 \mathrm{~h}$. A similar observation was made by Miller, Critser \& Ginther (1982) during an 8-day period of treatment with bovine follicular fluid and they concluded that this was due to a decrease in endogenous inhibin production by the ovary. The bovine follicular fluid used in the present study was, however, still effectively suppressing FSH secretion on Day 8 of treatment. FSH levels already appear to be decreasing at the start of the frequent sampling period $1 \mathrm{~h}$ after administration of follicular fluid and continue to fall throughout the 6-h bleed. More recent studies (J. M. Wallace \& A. S. McNeilly, unpublished observation) in which samples were withdrawn at 15-min intervals for $24 \mathrm{~h}$ after follicular fluid injections $(09: 00$ and $17: 00 \mathrm{~h})$ indicate that FSH levels do rebound slightly from around $06: 00 \mathrm{~h}$. This suggests that sampling at $09: 00 \mathrm{~h}$ probably gave an inaccurate picture of the degree of FSH suppression achieved by the treatment.

A gradual onset of refractoriness to the FSH-suppressing effects of follicular fluid has been observed following repeated administration of porcine follicular fluid to monkeys (Channing, Tanabe, Turner \& Hodgen, 1982) and rats (Thomas \& Nikitovitch-Winer, 1984). This was attributed to foreign proteins in the follicular fluid inducing an immunological response capable of inhibiting the FSH-suppressing activity of the fluid. Whilst the possible immunogenic properties of bovine follicular fluid cannot be ignored in the sheep it is doubtful, because of the short duration of treatment and its continuing effectiveness, whether this is the cause of the apparently higher FSH concentrations in the second part of the treatment cycle in this study.

After the cessation of follicular fluid treatment at the induced luteolysis, FSH levels showed a significant rebound to reach levels 3-4-fold higher than those of controls. The magnitude of this rebound appears to be correlated with both the length of treatment and the degree of FSH inhibition during treatment (Miller et al., 1982; J. M. Wallace \& A. S. McNeilly, unpublished observations). This rebound may reflect a release of an accumulation of FSH stores or substances involved in FSH synthesis in the pituitary once the effects of follicular fluid have ceased.

The hypersecretion of FSH observed in this and other studies (DePaolo et al., 1979; Hermans et al., 1981) may equally be the result of low endogenous inhibin and steroid(s) production due to insufficient FSH stimulation of follicular growth during the period of treatment with follicular fluid. Then, when the treatment ends, the pituitary releases its stores of FSH and follicular development progresses. Once the growing follicles secrete sufficient inhibin and steroid(s) into the circulation the rebound ceases.

Reports of the effects of follicular fluid on LH secretion in vivo and in vitro are inconsistent (Charlesworth, Grady \& Schwartz, 1983). Enhanced plasma LH concentrations after follicular fluid treatment have been observed in the ovariectomized mare (Miller et al., 1979) and mouse (Bronson \& Channing, 1979) coincident with the FSH suppression, and in intact rats after the depression of FSH had ceased (Hermans et al., 1981). Conversely, a decrease in LH secretion has been reported when a high dose of follicular fluid was given to ovariectomized ewes (Cummins et al., 1983). However, the majority of studies report no detectable effect on LH secretion (Campbell \& Schwartz, 1979; DePaolo et al., 1979; Thomas \& Nikitovitch-Winer, 1984) although the sampling frequency in all of these studies was inadequate to define possible differences in pulsatile LH frequency or amplitude. McNeilly (1984) has shown that injection of bovine follicular fluid to ewes in the preovulatory phase of the cycle did not affect the normal increase in pulsatile secretion of LH which is near maximum. In contrast, in the present study, follicular fluid injections in the luteal phase were associated with an increase in pulsatile LH secretion at a time when endogenous pulsatile secretion is normally suppressed. Since increased pulsatile LH secretion in intact ewes has been observed after immunization against androstenedione and oestradiol-17 (Martensz et al., 1976; Martensz \& Scaramuzzi, 1979) and is thought to arise because of a lack of negative feedback 
by oestradiol on LH secretion, it seems likely in the present study that the low FSH levels produced by the follicular fluid treatment resulted in less oestradiol being secreted from the follicles, with a consequent loss of negative feedback by oestradiol and hence an increase in pulsatile LH release.

The injection of bovine follicular fluid throughout the luteal phase resulted in a significant delay in the onset of oestrus. Since behavioural oestrus is an oestrogen-dependent event (Robinson, 1959) the delay is probably a result of insufficient oestradiol secretion by the developing follicle population immediately after luteal regression. Studies on monkeys (Channing et al., 1981) and sheep (Miller et al., 1979) indicate that suppression of FSH by follicular fluid resulted in significant follicular inhibition. The delay in oestrus in the follicular fluid-treated animals of the present study suggests that, at luteal regression, follicles that are destined to ovulate are less well developed than those of control ewes, presumably as a result of the reduction in plasma levels of FSH throughout the luteal phase. Consequently, these follicles take longer to respond to the increase in LH/FSH to become preovulatory.

Treatment with bovine follicular fluid did not alter the magnitude and duration of the preovulatory LH or coincident FSH surges and their timing relative to behavioural oestrus. This supports the concept that the events resulting in the onset of oestrus were simply delayed due to the lack of follicular development rather than being altered in any way.

It has been suggested that ovulation rate in the sheep is related to the amount of FSH released before and during the preovulatory (Lahlou-Kassi et al., 1984) and second surge (Cahill et al., 1981; Lahlou-Kassi et al., 1984) of FSH. However, the second FSH surge was suppressed in the present study and was associated with an increase in ovulation rate. The most probable reason for the observed increase in ovulation rate is the hypersecretion of FSH during the follicular phase after cessation of follicular fluid treatment at luteolysis, because administration of exogenous FSH (Wright, Bondioli, Grammer, Kuzan \& Menino, 1981 ; Baird, McNeilly, Wallace \& Webb, 1984) or of preparations with FSH-like activity, such as PMSG, after luteal regression (Robinson, 1951; Gordon, 1958; Gherardi \& Lindsay, 1980) have been shown to increase ovulation rates. The possible contribution of altered LH secretion relative to observed changes in ovulation rate in this study cannot be ignored. The frequent sampling period during the follicular phase did not reveal any major differences in pulsatile $\mathrm{LH}$ secretion between the two groups but the samples were withdrawn at a totally different time relative to the onset of oestrus. Since LH pulse frequency increases and amplitude decreases during the follicular phase until the onset of oestrus (Baird, 1978), the sampling window in this study cannot accurately be used for comparative purposes. However, a previous study also failed to detect any difference in pulsatile LH secretion during the preovulatory phase in ewes with nutritionally induced differences in ovulation rate (Scaramuzzi \& Radford, 1983). Furthermore, administration of exogenous pulses of GnRH in the preovulatory phase to increase LH secretion did not affect ovulation rate or LH secretion (McLeod \& Haresign, 1984).

In contrast, the increase in LH pulse frequency and amplitude measured in the luteal phase of this study is consistent with that observed following immunization of ewes against both androgens and oestrogens (Martensz et al., 1976; Martensz \& Scaramuzzi, 1979). The increase in ovulation rate observed after immunization occurs in spite of variable or low FSH concentrations. Whether the follicular population in the present study is sufficiently developed to benefit from such an increase in pulsatile $\mathrm{LH}$ is unknown.

These results suggest that the increase in ovulation rate in ewes after treatment with bovine follicular fluid is associated with the change in gonadotrophin secretion during the luteal and follicular phases of the cycle. Whether this is related entirely to the altered pattern of FSH secretion, the increase in LH secretion or a combination of the two remains to be clarified.

We thank Miss N. Anderson, Miss H. Ainslie and Mr B. Ogilvie for skilled technical assistance; Miss M. Fordyce and the staff at ABRO Dryden Field Station for performing the laparoscopies; the NIADDK and Dr S. S. Lynch and Dr J. E. T. Corrie for some hormone 
preparations and antiserum; Mr T. McFetters and Mr E. Pinner for preparation of the figures; Mrs P. Warner for statistical advice; Mrs A. Shaw for typing; and Professor D. T. Baird for advice and assistance. J.M.W. is in receipt of a postgraduate studentship from the Department of Agriculture and Fisheries for Scotland.

\section{References}

Backström, C.T., McNeilly, A.S., Leask, R.M. \& Baird, D.T. (1982) Pulsatile secretion of LH, FSH, prolactin, oestradiol and progesterone during the menstrual cycle. Clin. Endocr. 17, 29-42.

Baird, D.T. (1978) Pulsatile secretion of LH and ovarian estradiol in the follicular phase of the sheep estrous cycle. Biol. Reprod. 18, 359-364.

Baird, D.T. (1983) Factors regulating the growth of the preovulatory follicle in the sheep and human. $J$. Reprod. Fert. 69, 343-352.

Baird, D.T., McNeilly, A.S., Wallace, J.M. \& Webb, R. (1984) Infusion of FSH increases ovulation rate in Welsh Mountain ewes. Proc. Vth Reinier de Graaf Symposium, Abstr. 13.

Betteridge, K. J. (1981) An historical look at embryo transfer. J. Reprod. Fert. 62, 1-13.

Bindon, B.M., Blanc, M.R., Pelletier, J., Terqui, M. \& Thimonier, J. (1976) Oestrus et ovulation chez la brebis apres induction de la luteolyse par un analogue des prostaglandes dans quatre troupeaux de prolificate differente. Annls Biol. anim. Biochim. Biophys. 16, 169, Abstr.

Bronson, F.H. \& Channing, C.P. (1978) Suppression of serum follicle stimulating hormone by follicular fluid in the maximally estrogenized ovariectomized mouse. Endocrinology 103, 1894-1898.

Cahill, L.P., Saumande, J., Ravault, J.P., Blanc, M., Thimonier, J., Mariana, J.C. \& Mauléon, P. (1981) Hormonal and follicular relationships in ewes of high and low ovulation rates. J. Reprod. Fert. 62, 141150.

Campbell, C.S. \& Schwartz, N.B. (1979) Time course of serum FSH suppression in ovariectomized rats injected with porcine follicular fluid (folliculostatin): effect of estradiol treatment. Biol. Reprod. 20, 10931098.

Channing, C.P., Tanabe, K., Turner, C.K. \& Hodgen, G.D. (1982) Antisera to porcine follicular fluid in monkeys: neutralization of human and pig inhibin activity in vivo and in vitro. J. clin. Endocr. Metab. 55, 481-486.

Chappel, S.C. \& Selker, F. (1979) Relation between the secretion of FSH during the periovulatory period and ovulation during the next cycle. Biol. Reprod. 21, 347352.

Charlesworth, M.C., Grady, R.R. \& Schwartz, N.B. (1983) The effect of GnRH on the specificity of gonadotropin response to follicular fluid in vivo. In Factors Regulating Ovarian Function, pp. 169-173. Eds G. S. Greenwald \& P. F. Terranova. Raven Press, New York.

Cummins, L.J., O'Shea, T., Bindon, B.M., Lee, V.W.K. \& Findlay, J.K. (1983) Ovarian inhibin content and sensitivity to inhibin in Booroola and control strain Merino ewes. J. Reprod. Fert. 67, 1-7.

de Jong, F. H. \& Sharpe, R. M. (1976) Evidence for inhibin-like activity in bovine follicular fluid. Nature, Lond. 263, 71-72.

DePaolo, L.V., Hirshfield, A.N., Anderson, L.D., Barraclough, C.A. \& Channing, C.P. (1979) Suppression of pituitary secretion of follicle-stimulating hormone by porcine follicular fluid during prooestrus and oestrus in the rat: effects on gonadotrophin and steroid secretion, follicular development and ovulation during the following cycle. J. Endocr. $83,355-368$.

di Zerega, G.S., Marrs, R.P., Roche, P.C., Campeau, J.D. \& Kling, O.R. (1983) Identification of proteins in pooled human follicular fluid which suppress follicular response to gonadotrophins. J. clin. Endocr. Metab. 56, 35-41.

Djahanbahkch, O., Swanston, I.A., Corrie, J.E.T. \& McNeilly, A.S. (1981) Prediction of ovulation by progesterone. Lancet 8256, 1164-1165.

Findlay, J.K. \& Cumming, I.A. (1976) FSH in the ewe: effects of season, live weight and plane of nutrition on plasma FSH and ovulation rate. Biol. Reprod. 15, 335-342.

Gherardi, P.B. \& Lindsay, D.R. (1980) The effect of season on the ovulatory response of Merino ewes to serum from pregnant mares. J. Reprod. Fert. 60, 425429.

Goodman, R.L., Pickover, S.M. \& Karsch, F.J. (1981) Ovarian feedback control of follicle-stimulating hormone in the ewe: evidence for selective suppression. Endocrinology 108, 772-777.

Gordon, I. (1958) The use of progesterone and serum gonadotrophin (PMS) in the control of fertility in sheep. J. agric. Sci., Camb. 50, 123-197.

Henderson, K.M. \& Franchimont, P. (1983) Inhibin production by bovine ovarian tissues in vitro and its regulation by androgens. J. Reprod. Fert. 67, 291298.

Hermans, W.P., Debets, M.H.M., van Leeuwen, E.C.M. \& de Jong, F.H. (1981) Time-related secretion of gonadotrophins after a single injection of steroid-free bovine follicular fluid in prepubertal and adult female rats. J. Endocr. 90, 69-76.

Lahlou-Kassi, A., Schams, D. \& Glatzel, P. (1984) Plasma gonadotrophin concentrations during the oestrous cycle and after ovariectomy in two breeds of sheep with low and high fecundity. J. Reprod. Fert. 70, 165173.

Marder, M.L., Channing, C.P. \& Schwartz, N.B. (1977) Suppression of serum follicle stimulating hormone in intact and acutely ovariectomized rats by porcine follicular fluid. Endocrinology 101, 1639-1642.

Martensz, N.D. \& Scaramuzzi, R.J. (1979) Plasma concentrations of luteinizing hormone, follicle-stimulating hormone and progesterone during the breeding season in ewes immunized against androstenedione or testosterone. $J$. Endocr. 81, 249-259, 
Martensz, N.D., Baird, D.T., Scaramuzzi, R.J. \& Van Look, P.F.A. (1976) Androstenedione and the control of luteinizing hormone in the ewe during anoestrus. $J$. Endocr. 69, 227-237.

McLeod, B.J. \& Haresign, W. (1984) Plasma LH concentrations in the ewe in response to repeated injections of low doses of gonadotrophin releasing hormone during the follicular phase of the oestrous cycle. J. Endocr. 101, 365-370.

McNeilly, A.S. (1984) Changes in FSH and the pulsatile secretion of LH during the delay in oestrus induced by treatment of ewes with bovine follicular fluid. $J$. Reprod. Fert. 72, 165-172.

McNeilly, A.S. \& Andrews, P. (1974) Purification and characterization of caprine prolactin. J. Endocr. 60, 359-367.

McNeilly, J.R., McNeilly, A.S., Walton, J.S. \& Cunningham, F.J. (1976) Development and application of a heterologous radioimmunoassay for ovine folliclestimulating hormone. J. Endocr. 70, 69-79.

Miller, K.F., Critser, J.K., Rowe, R.F. \& Ginther, O.J. (1979) Ovarian effects of bovine follicular fluid treatment in sheep and cattle. Biol. Reprod. 21, 537544.

Miller, K.F., Wesson, J.A. \& Ginther, O.J. (1981) Interaction of estradiol and a nonsteroidal follicular fluid substance in the regulation of gonadotropin secretion in the mare. Biol. Reprod. 24, 354-358.

Miller, K.F., Critser, J.K. \& Ginther, O.J. (1982) Inhibition and subsequent rebound of FSH secretion following treatment with bovine follicular fluid in the ewe. Theriogenology 18, 45-53.

Robinson, T.J. (1951) The control of fertility in sheep. Part II. The augmentation of fertility by gonadotrophin treatment of the ewe in the normal breeding season. J. agric. Sci., Camb. 41, 6-63.
Robinson, T.J. (1959) The estrous cycle of the ewe and doe. In Reproduction in Domestic Animals, Vol. 2, pp. 291-333. Eds H. H. Cole \& P. T. Cupps. Academic Press, New York.

Scaramuzzi, R.J. \& Radford, H.M. (1983) Factors regulating ovulation rate in the ewe. J. Reprod. Fert. 69, 353-367.

Sheela Rani, C.S. \& Moudgal, N.R. (1977) Role of the proestrous surge of gonadotrophins in the initiation of follicular maturation in the cyclic hamster. A study using antisera to follicle stimulating hormone and luteinizing hormone. Endocrinology 101, 1484-1494.

Thomas, C.L. \& Nikitovitch-Winer, M.A.B. (1984) Complete suppression of plasma follicle-stimulating hormone in castrated male and female rats during continuous administration of porcine follicular fluid. Biol. Reprod. 30, 427-433.

Welschen, R., Hermans, W.P., Dullaart, J. \& de Jong, F.H. (1977) Effects on an inhibin-like factor present in bovine and porcine follicular fluid on gonadotrophin levels in ovariectomized rats. J. Reprod. Fert. 50, 129-131.

Welschen, R., Hermans, W.P. \& de Jong, F.H. (1980) Possible involvement of inhibin in the interrelationship between numbers of antral follicles and peripheral FSH concentrations in female rats. $J$. Reprod. Fert. 60, 485-493.

Wright, R.W., Jr, Bondioli, K., Grammer, J., Kuzan, F. \& Menino, A., Jr (1981) FSH or FSH plus LH superovulation in ewes following estrus synchronization with medoxyprogesterone acetate pessaries. J. Anim. Sci. 52, 115-118. 